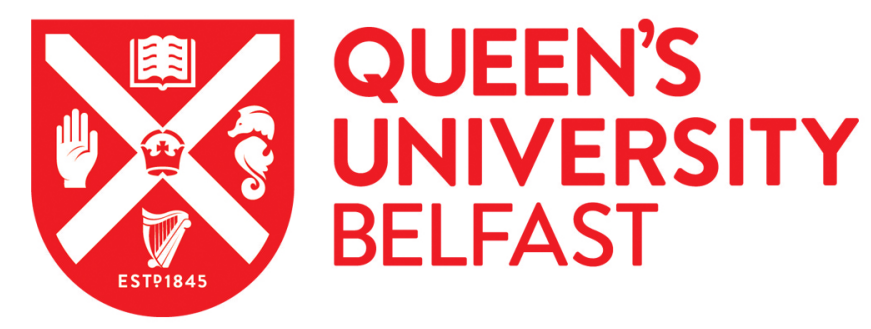

\title{
Reconciliation and Intergroup Forgiveness: The case of the Kurdish conflict in Turkey
}

Baysu, G., \& Coskan, C. (2018). Reconciliation and Intergroup Forgiveness: The case of the Kurdish conflict in Turkey. Turkish Studies, 19(5), 748-772. https://doi.org/10.1080/14683849.2018.1484287

\section{Published in:}

Turkish Studies

\section{Document Version:}

Peer reviewed version

Queen's University Belfast - Research Portal:

Link to publication record in Queen's University Belfast Research Portal

\section{Publisher rights}

Copyright 2018 Taylor and Francis. This work is made available online in accordance with the publisher's policies. Please refer to any applicable terms of use of the publisher.

\section{General rights}

Copyright for the publications made accessible via the Queen's University Belfast Research Portal is retained by the author(s) and / or other copyright owners and it is a condition of accessing these publications that users recognise and abide by the legal requirements associated with these rights.

Take down policy

The Research Portal is Queen's institutional repository that provides access to Queen's research output. Every effort has been made to ensure that content in the Research Portal does not infringe any person's rights, or applicable UK laws. If you discover content in the Research Portal that you believe breaches copyright or violates any law, please contact openaccess@qub.ac.uk. 
Reconciliation and Intergroup Forgiveness: The case of the Kurdish conflict in Turkey

\title{
Gülseli Baysu and Canan Coşkan
}

\begin{abstract}
Author Note
Gülseli Baysu, Psychology, Queen’s University Belfast, G.baysu@qub.ac.uk

Canan Coşkan, Institute for Interdisciplinary Conflict and Violence Research, Bielefeld

University, canancoskan@gmail.com
\end{abstract}

Correspondence concerning this article should be addressed to Dr. Gülseli Baysu, School of Psychology, Queen's University Belfast. Address: University Road, Belfast, Ulster BT7 1NN, Northern Ireland, United Kingdom. Email: g.baysu@qub.ac.uk, gulseli.baysu@gmail.com 


\title{
Reconciliation and Intergroup Forgiveness: The case of the Kurdish conflict in Turkey
}

\begin{abstract}
Looking at the Kurdish conflict, we examined how Kurds and Turks in Turkey and in diaspora (Belgium) construe reconciliation and how they approach reconciliation and intergroup forgiveness. Kurds' construals of reconciliation tapped into seven themes, grouped as dialogue-based construal of reconciliation (themes: dialogue, recognition, emotions and peace) vs. rights-based construal (themes: identity rights, freedom and confederative rights). Turks' construals of reconciliation covered eight themes, grouped as unity-based construal of reconciliation (themes: unity, rights, dialogue, recognition, and emotions), disarming PKKbased construal of reconciliation (themes: disarming PKK and peace) and rejecting reconciliation (theme: rejection of reconciliation). Kurds endorsing the emotion and dialogue themes and Turks endorsing a unity-based construal of reconciliation were more forgiving of the other group. Implications of these different meanings and relationships of reconciliation are discussed.
\end{abstract}

Keywords: Reconciliation, Intergroup forgiveness, Kurdish conflict, Conflict construals, Diaspora, Turkey 


\section{Reconciliation and Intergroup Forgiveness: The case of the Kurdish conflict in Turkey}

In today's world, most countries are plural societies, in the sense that they are composed of different ethnic, racial or religious groups. From a social and political psychology perspective, most conflicts arise from intergroup tensions in such plural societies ${ }^{1}$. While some of these conflicts are small-scale local intergroup tensions, others expand through time and geography and escalate in intensity to the point of creating dynamics of violent oppression and violent responses to them as in the cases of post-Cold War (such as in Yugoslavia) $^{2}$ and independence struggles (such as in Columbia) ${ }^{3}$. Intense intergroup conflicts affect not only those countries devastated by prolonged (armed) conflict between different groups, but also those more developed countries, for instance, with an inflight of refugees. Even when the violent conflict is over or halted, the hostility between groups remain, preparing a cradle for future conflicts.

Reconciliation is important to achieve long-term peaceful relations following a violent conflict. ${ }^{4}$ Despite diverging conceptualizations in the social sciences, many approaches agree that reconciliation, as different from the conflict resolution, is defined as a societal and psychological process requiring changes of motivations, attitudes and emotions by members of the society, which is accompanied by structural acts of political and economic integration. ${ }^{5}$ It also involves the removal of psychological barriers which block the path to restore positive identities and discordant relationships. ${ }^{6}$

Intergroup forgiveness is similarly defined as a change of motivations and restoration of discordant relationships by abandoning the negative feelings towards a perpetrating outgroup. Intergroup forgiveness is related to reconciliation because it has a potential value to reduce the negative effects of prolonged conflicts and the hostility between groups which may continue when the conflict is over. ${ }^{7}$

In this study, deriving mainly from social and political psychology literature, we aim to understand to what extent both sides of the Kurdish conflict in Turkey - the Kurdish minority and the Turkish majority - support reconciliation as a desired outcome, what reconciliation means for them (i.e., reconciliation construals), and how they approach intergroup forgiveness. Moreover, we aim to investigate the relations between reconciliation and intergroup forgiveness as different aspects of peacebuilding process. In doing this, we take a transnational approach by comparing the situation in Turkey and its spill-over in Belgium. Social and political psychology literature has a lot to offer in analysing psychological aspects of reconciliation and intergroup forgiveness by taking into account motivations, attitudes and emotions of individuals who identify with and belong to the 
conflicting groups. In the following sub-sections, we first give a short summary of the Kurdish conflict in Turkey and its spill-over in Belgium, then we provide the social and political psychology framework of reconciliation and intergroup forgiveness in intractable conflicts along with our expectations.

\section{The context: The Kurdish conflict in Turkey and its spill-over in Belgium}

Kurds are the largest minority group in Turkey - an estimated 15-20 per cent of the population. ${ }^{8}$ The tension between the Kurdish minority group and the Turkish majority group can be traced back to the fall of Ottoman Empire and the foundation of Turkish Republic in 1923. ${ }^{9}$ After the demise of the Ottoman Empire, the Turkish state was founded on the ideals of national unity, with Turkish as the national language and the ethnic Turks as the founders. The recognition of different minority groups or their cultural rights has been largely neglected for a long period of time in Turkey. Efforts by Kurds to move towards political representation and recognition of their ethnic identity have been marred by oppression, hence creating ground for "intrastate" conflict. ${ }^{10}$ The armed conflict between the Kurdistan Workers' Party (PKK) and the Turkish State dates back to mid-1980s. Although a reliable estimate is impossible to reach, an estimated 30.000-40.000 people from both sides of the conflict have been killed in this conflict, which mostly occurred in south-eastern Turkey. ${ }^{11}$ During the socalled peace process which involved the official reconciliation negotiations between 20122015, there was some progress towards cease-fire and granting cultural rights. The negotiations between the parties began earlier in 2008-2009. ${ }^{12}$ Our study took place during the ceasefire while the peace negotiations were continuing. The so-called peace process was recently halted and the violent armed conflicts have resumed. ${ }^{13}$

The intergroup tension between Kurds and Turks often spills over to European countries where many immigrants from Turkey reside. ${ }^{14}$ For instance, Alinia and Eliassi's qualitative research of Kurdish diaspora in Sweden shows that intergroup tensions are intense particularly among the second-generation youth ${ }^{15}$. We focus on Belgium, as an exemplary case where immigrants from Turkey are one of the biggest immigrant groups - one and a half per cent of the population. There is not much statistics about different ethnic groups who migrated from Turkey to Belgium. ${ }^{16}$ Reflecting the situation in their homeland, the intergroup tension between Kurds and Turks shows itself in Belgium through riots and protests, especially in times of escalating homeland political conflicts, from both sides and sometimes toward each other or to those third parties who support either diaspora communities. ${ }^{17}$ Advancement of peace-process became a matter of political discussion in Belgium since Belgian (particularly the Flemish) politics was receptive to the Kurdish cause but their 
advocacy was limited to the personal commitments of individual politicians and Kurdish activists $^{18}$

Moreover, what makes this transnational comparison interesting from a social psychological perspective is that the majority-minority status of Kurds and Turks differ in both countries: while in Turkey, Kurds are the minority group and Turks are the majority group, in Belgium they are both minority groups from Turkey, mobilizing as minority communities. ${ }^{19}$ Therefore, it would be theoretically interesting to investigate across both countries to what extent the national Zeitgeist of the Kurdish-Turkish relations is mirrored upon the transnational context in terms of the support for and construals of reconciliation, and intergroup forgiveness.

\section{Reconciliation and Intergroup Forgiveness}

Reconciliation is a long process and a desired outcome for stable and lasting peace. ${ }^{20}$ First, it is a psychological process of changes in motivations, attitudes and emotions by the majority of society. ${ }^{21}$ Second, reconciliation is also an outcome described as 'Trustworthy positive relations between former adversaries who enjoy secure social identities and interact in an equality-based social environment'.$^{22}$ During intrastate conflict resolution, the structural component of that outcome requires political and economic integration, that is, all parties of the conflict should benefit from equal opportunities and rights and this can only be achieved through political and economic restructuring of the state institutions and policies. ${ }^{23}$ Accordingly, for reconciliation, structural changes toward political and economic integration should be accompanied by psychological changes that support it. ${ }^{24}$

Empirically, most social and political psychological research does not directly test reconciliation ${ }^{25}$; the focus is on other intergroup outcomes related to reconciliation such as intergroup attitudes, forgiveness, attributions of responsibility, and distance. ${ }^{26}$ As such, little can be revealed about the content of reconciliation or the reasons of support for reconciliation as understood and endorsed by the society. Other researchers adopted a measurement scale approach to reconciliation asking respondents their agreement on predetermined themes. The content of such scales, however, differ across conflicts. For instance, reconciliation has been defined as trust, collaboration with outgroup members and the capacity to control oneself in the presence of the offenders in the Rwandan conflict or as awareness of the need to talk to and interact with the other community in the Northern Ireland conflict. ${ }^{27}$ Put differently, the meaning of reconciliation will be at least partially bound by the context specificity of the unique conflict and its resolution. Therefore, one needs to reveal the meaning and content of 
the reconciliation to better understand the dynamics of the (lack of) support for reconciliation in a given society.

There is also a growing line of research in social and political psychology of conflicts with a bottom-up approach to different understandings of the nature of the conflict in which people are involved. Conflict frames are important as they hint at people's subjective evaluation of the conflicts such as attributions of responsibility and sense of victimization. ${ }^{28}$ Conflict frames are associated with outgroup (dis)trust and attitudes towards reconciliation. ${ }^{29}$ In the Kurdish conflict, based on the discussions by members of Turkish academy and NGOs in a workshop on Kurdish question in Turkey, Çelik and Blum talks about three conflict frames depending on how the parties involved in the conflict are defined: (1) a conflict between the Turkish state and the PKK (the terrorism frame), (2) a conflict between the Turkish state and the residents of Southeast Turkey (minority rights frame), (3) a conflict between Turks and Kurds (ethnic tensions frame). ${ }^{30}$ Uluğ and Cohrs focused not only on the parties involved but also on representations of the conflict and on suggested solutions by interviewing lay people in Turkey and applying Q-sorting methodology to their responses: In addition to terrorism and minority rights frames, they found that representations of external powers' threat went together with economic issues, suggesting economic development as the solution for the conflict. ${ }^{31}$ They also found a separate independence representation (suggesting independent Kurdistan as the solution), which was endorsed only by Kurdish respondents.

We conceptualize reconciliation both as an outcome and as a process. Considering it as an outcome, we ask our respondents to what extent they support reconciliation as a desired outcome. To understand the process of reconciliation, we believe an empirically-driven, bottom-up approach is required to grasp how people construe reconciliation (similar to studies of conflict construals). We ask Kurdish and Turkish respondents what reconciliation means to them and how it can be achieved, and use content-coding to derive at various themes. Since minority and majority groups differ in the access to and representation of socio-political discourses, we chose to examine the themes and conduct the thematic coding separately for the Kurdish and Turkish respondents. ${ }^{32}$ We then do a Latent Class Analysis to see whether our respondents holding similar understandings of reconciliation can be grouped along these themes.

Additionally, we examine intergroup forgiveness. Forgiveness is defined as 'a willingness to abandon's one's right to resentment, negative judgment, and indifferent behavior toward one who unjustly hurt us' ${ }^{33}$ Linking interpersonal forgiveness to intergroup 
forgiveness, this resentment may be towards a group rather than an individual. Intergroup forgiveness is defined as a change of motivation towards a perpetrating out-group within a specific political or societal context. ${ }^{34}$ Looking at intergroup forgiveness is crucial, since the hostility between groups remain without the apology-forgiveness cycle, creating the potential for future conflicts. ${ }^{35}$ Thus intergroup forgiveness is recognized as one way of reducing the negative effects of prolonged armed conflicts. ${ }^{36}$

In sum, in the Kurdish conflict, during the time when so-called "peace process" was going on, we looked at how support for reconciliation, reconciliation construals and intergroup forgiveness were related and whether these relations diverged between Kurds and Turks in Belgium and in Turkey.

\section{Method}

\section{Respondents}

Kurdish respondents were from Turkey ( $n=75,33 \%$ female) and Belgium ( $n=66$, $29 \%$ female), with the age range of 17 to 51 years $(M=27.24$, $S D=6.94)$, though $86.5 \%$ of respondents were younger than 34. Respondents in Belgium (Leuven, Antwerp, Brussels and Gent) were immigrants from Turkey (Mage of immigration $=20.71)$ with $51.5 \%$ stating their reason of immigration as seeking political refuge. Respondents in Turkey (Istanbul) were internal immigrants. Both in Turkey and Belgium, they were mostly first-generation immigrants emigrated from south-eastern Turkey (92\% and 88\% respectively). Most respondents were highly educated (55.3\% being university students or university graduates).

Turkish respondents were from Turkey ( $n=40,20 \%$ female) and Belgium ( $n=46,52 \%$ female), with the age range of 19 to 56 years $(M=27.21, S D=8.24) .80 \%$ of the respondents were younger than 34. Respondents in Belgium were immigrants from Turkey (Mage of immigration $=22.84 ; S D=9.06)$. Almost half of the respondents were highly-educated $(44.2 \%$ being university students or university graduates). We focused on the same cities and similar age and education range as the Kurdish sample. The reason behind our focus on big cities is that of the eleven million Kurdish minorities in Turkey, an estimated two million of them live in Istanbul. ${ }^{37}$ Istanbul hosts the largest group of the Kurdish minority in Turkey. Similarly, Turkish and Kurdish immigrants in Belgium are concentrated in urban areas.

\section{Procedure}

Respondents from both countries were reached by convenience sampling method and they completed the questionnaires during one-to-one meetings arranged and conducted by a male research assistant fluent in both Kurdish and Turkish. Respondents, all competent in Turkish, received the questionnaire in Turkish. Confidentiality and anonymity was ensured. 


\section{Measures}

Support for Reconciliation. We measured respondents' support for reconciliation with two items: "How desirable do you think is reconciliation?" and "How realistic/likely do you think is reconciliation?". ${ }^{38}$ Answers were recorded on five-point Likert scales $(1=$ Not Likely, $5=$ Very Likely). A composite score was computed from the two items (For Kurds, SpearmanBrown $\rho=.57, p<.001, M=2.92, S D=1.08$; For Turks, Spearman-Brown $\rho=.54, p<.001 ; M$ $=2.80, S D=1.04$ ).

Reconciliation Construals. How respondents construed the reconciliation was measured by an open-ended question: "What does reconciliation mean to you and how can it be achieved?" Answers were qualitatively explored for themes appearing for more than once, then they were content-coded based on the emerging themes by screening each response for each theme and finally, a latent class analysis was performed on those themes (see the Results section).

Intergroup forgiveness. We measured intergroup forgiveness by five items, adapted from Moeschberger and collegues ${ }^{39}$. Items were "it is important that my group never forgets the wrongs done to us by the other group" (reverse coded), "it is important that my group never forgives the wrongs done to us by the other community" (reverse coded), "forgiving the other group for past wrongs would be disloyal to my own group" (reverse coded), "only when the two groups in Turkey learn to forgive each other can we be free of political violence", and "it is necessary to forgive each other for the sake of a better future". Answers were given on seven-point Likert scales ( 1 =Strongly disagree, $7=$ Strongly agree $)$. Scale was reliable, for Kurds $\alpha=.75$, for Turks $\alpha=.76$.

Ingroup Identifications. We measured ingroup identities, i.e., Kurdish identification for Kurds and Turkish identification for Turks with the traditional item used to measure social identities in seven-point Likert scales ( 1 =Not at All, 7 =Very Strongly): Among Kurds, "to what extent do you identify with Kurds" $(M=6.4, S D=1.38)$ and among Turks "to what extent do you identify with Turks" $(M=6.08, S D=1.65) .{ }^{40}$

\section{Results}

\section{Reconciliation construals}

First, Kurdish and Turkish respondents' descriptions of reconciliation were separately evaluated by two independent raters for relevant themes. Seven themes emerged from 109 answers of Kurdish respondents (See Table 1, first and second columns) and eight themes emerged from 61 answers of Turkish respondents (See Table 2, first and second columns). Second, three independent raters conducted fully-crossed content-coding for 109 answers from Kurds in the frame of seven themes; and two independent raters followed the same 
strategy for 61 answers from Turks in the frame of eight themes. Each answer was screened based on whether it included (1) or did not include (0) each of the themes.

For instance, a Kurdish respondent's description of reconciliation as "Reconciliation means mutual respect for opinions of different groups. For reconciliation to take place, these groups need to listen to each other without fighting" was coded as 1 under the themes of Dialogue and Respect and as 0 for the other five themes. Another Kurdish respondent's description of reconciliation as "Creating a context in which Kurds can freely live on their lands and to come to the table with PKK to resolve the conflict" was coded as 1 under the themes of Freedom and Confederation and as 0 for the other five themes.

A Turkish respondent's description of reconciliation as "Reconciliation means mutual respect from both parties, rights to preserve cultural values and an integrative approach to society" was coded as 1 under the themes of Rights, Recognition and Unity and as 0 for the other five themes. Another Turkish respondent's description of reconciliation as "PKK should drop weapons for peace" was coded as 1 under the theme of Disarming PKK and Peace and as 0 for the other six themes. A third Turkish respondent's description of reconciliation as "I don't think that what is referred as reconciliation is clear enough; it seems like a bargaining for other kinds of actions. Why now? Why weren't there any attempts for reconciliation until now?" was coded as 1 under the theme of Rejection and as 0 for the other seven themes.

Inter-rater reliability analyses using the Kappa statistic indicated consistency among raters for each theme (see Table 1 and Table 2, final columns). The total average inter-rater reliability for Kurds' responses was close to perfect $\kappa=.97(p<.001)$ and for Turks', it was above the acceptable range $\kappa=.84(p<.001) .{ }^{41}$

Finally, two series of Latent Class Analyses (LCA) were conducted separately to group Kurdish people who hold similar understandings of reconciliation along seven themes, and Turkish people who hold similar understandings of reconciliation along eight themes. To this end, seven (for Kurds) and eight (For Turks) dummy-coded variables indicating the seven and eight themes were analysed in LCA. Similar to factor analysis which assumes existence of latent dimensions, LCA assumes existence of latent groups of subjects and that within the same latent group, respondents respond to various items similarly. Deciding on the number of clusters in LCA is a function of better fit statistics and interpretability ${ }^{42}$. 
Table 1

Themes, Contents, and Inter-rater Reliabilities for Kurds'Reconciliation Construals

\begin{tabular}{|c|c|c|}
\hline Themes & Respondents' emphasis on: & $\begin{array}{l}\text { Averaged Inter-rater } \\
\text { reliability }(\boldsymbol{k})(n=3)\end{array}$ \\
\hline Rights & $\begin{array}{l}\text { Kurdish rights, demands of language, education, } \\
\text { political autonomy and equality }\end{array}$ & $0.93(p<.001)$ \\
\hline Freedom & $\begin{array}{l}\text { Free choice of people (on the political system, on } \\
\text { the importance of cultural codes etc.) as well as } \\
\text { freedom to Abdullah Öcalan }\end{array}$ & $0.96(p<.001)$ \\
\hline Confederation & $\begin{array}{l}\text { Kurdish independence, autonomous region, } \\
\text { confederation }\end{array}$ & $0.92(p<.001)$ \\
\hline Emotions & Empathy, Genuineness, Trust, Happiness. & $1.00(p<.001)$ \\
\hline Dialogue & $\begin{array}{l}\text { Intergroup communication, talking and } \\
\text { understanding }\end{array}$ & $1.00(p<.001)$ \\
\hline Recognition & Giving and getting recognition and respect. & $1.00(p<.001)$ \\
\hline Peace & Constructing peace, ending the war & $0.98(p<.001)$ \\
\hline
\end{tabular}

Table 2

Themes, Contents, and Inter-rater Reliabilities for Turks' Reconciliation Construals

\begin{tabular}{|c|c|c|}
\hline Themes & Respondents' emphasis on: & $\begin{array}{l}\text { Averaged Inter-rater } \\
\text { reliability }(\kappa)(n=2)\end{array}$ \\
\hline Peace & Constructing peace, ending the war & $0.79(p<.001)$ \\
\hline Disarming PKK & $\begin{array}{l}\text { In order to reach peace and reconciliation PKK } \\
\text { should drop arms }\end{array}$ & $0.62(p<.001)$ \\
\hline Rights* & Kurdish rights, demands of language, education & $0.94(p<.001)$ \\
\hline Dialogue & $\begin{array}{l}\text { Intergroup communication, talking and } \\
\text { understanding }\end{array}$ & $0.96(p<.001)$ \\
\hline Emotions & Empathy, Genuineness, Trust, Happiness. & $0.77(p<.001)$ \\
\hline Recognition & Giving and getting recognition and respect. & $0.91(p<.001)$ \\
\hline Unity & $\begin{array}{l}\text { Unity, Fraternity, (both assimilative -mostly } \\
\text { based on Turkish society and values and } \\
\text { integrative) Commonalities }\end{array}$ & $0.96(p<.001)$ \\
\hline Rejection & $\begin{array}{l}\text { Rejection of reconciliation (e.g. "reconciliation } \\
\text { is not genuine, it is a dirty bargaining" or the } \\
\text { denial of discrimination) }\end{array}$ & $0.74(p<.001)$ \\
\hline
\end{tabular}

*Unlike Kurds, Turks' understanding of "rights" was composed of cultural rights and did not include "political autonomy and equality".

For Kurds, comparing one to three-class solutions, a two-class solution was preferred as it provided better fit statistics and meaningful classes: Loglikelihood (LL) (112)= -381.697, AIC: 793.395, BIC: 833.765, Entropy: .64 (medium-level certainty). Odds ratio probability estimates showed that Rights, Freedom, and Confederation were most likely to be classified under Rights-based reconciliation, and Dialogue, Recognition, Peace, and Emotions were 
most likely to be classified under Dialogue-based reconciliation. Kurdish respondents' perceptions of reconciliation were then coded either as 0 for dialogue-based reconciliation (59\% of the respondents) or as 1 for rights-based reconciliation ( $41 \%$ of the respondents).

For Turks, comparing one to three-class solutions, a three-class solution was preferred as it provided better fit statistics and meaningful classes: Loglikelihood (LL) (229) $=-199.046$, AIC: 450.093, BIC: 504.546, Entropy: .99 (high-level certainty). Odds ratio probability estimates showed that Rights, Dialogue, Emotions, Recognition, and Unity were classified under Unity-based reconciliation; Peace and Disarming PKK were classified under Disarming-PKK-based reconciliation; and with the only theme of rejection, Rejection of reconciliation appeared as a third category. Turkish respondents' perceptions of reconciliation were then coded as 0 for disarming-PKK-based reconciliation ( $22 \%$ of the respondents), as 1 for unity-based reconciliation (60\%), and as 2 for rejection of reconciliation (18\%); however, for the interpretability of the correlations two dummies were created (Table 4b Reconciliation Construals -1 and -2 ).

\section{Comparison of Kurdish and Turkish Samples in Turkey and Belgium}

Means and standard deviations of measures are reported in Table 3. Kurds in Turkey and in Belgium had similar gender distributions but they differed in educational levels with fewer Kurds in Belgium having university degree than Kurds in Turkey. Kurds in Turkey were younger than Kurds in Belgium. Kurds' identification with their ingroup differed with those in Turkey having higher Kurdish identification than those in Belgium, although it was highly-skewed in both groups. Kurds in Turkey scored lower on support for reconciliation than Kurds in Belgium. The difference between those in Turkey and Belgium were not significant for either endorsement of different reconciliation construals or intergroup forgiveness.

Turks in Turkey displayed an unbalanced gender distribution with more male respondents than Turks in Belgium but they had similar educational levels with more than one third of respondents in Turkey and Belgium having a university degree. Similar to the Kurds' composition, Turks in Turkey were younger than Turks in Belgium. Turks' identification with their ingroup did not differ across countries and again, it was highly-skewed in both groups. Similar to Kurds, Turks in Turkey showed lower support for reconciliation. Additionally, Turks in Turkey talked less about reconciliation in terms of peace and disarming PKK, and more about rejecting reconciliation than Turks in Belgium. 
Table 3

Comparison of demographics and study variables across country of residence

\begin{tabular}{rrrllll}
\hline & Kurds & \multicolumn{5}{c}{ Turks } \\
\hline & & & Difference \\
& Turkey & Belgium & test & Turkey & Belgium & $\begin{array}{l}\text { Difference } \\
\text { test }\end{array}$ \\
\hline $\mathrm{N}$ & 75 & 66 & & 40 & 46 &
\end{tabular}

Gender

(\% male)

$\% 66.7 \quad \% 71.2 \quad p=.561 \quad \% 80 \quad \% 47.8 \quad p=.002$

Education

(university)

$\% 68 \% 40.9 \quad p=.005$

$\% 37.5 \% 50$

$p=.405$

$24.04 \quad 30.88$

$23.28 \quad 30.63$

Age

(3.98) (7.78) $\quad p<.001$

(5.36) (8.80)

$p<.001$

Ingroup

$6.69 \quad 6.06$

6.03

6.11

Identification

(0.59) (1.88) $\quad p=.007$

(1.72)

(1.61) $p=.826$

Support for

2.60

3.02

Reconciliation

(0.94)

(1.11)

2.54

3.25

Intergroup

$p=.016$

(1.02)

$p=.002$

forgiveness

(1.43)

(1.39)

4.83

$p=.748$

Reconciliation

Construals:

Kurds

Turks:

$\begin{array}{cccc}\text { Rights } & \% 42 & \% 40 & p=.836 \\ \text { Dialogue } & \% 58 & \% 60 & p=.836\end{array}$

$\begin{array}{rrrr}\text { Unity } & 64 \% & 55 \% & p=.441 \\ \text { Disarming } & 4 \% & 36 \% & p=.002 \\ \text { Rejection } & 32 \% & 9 \% & p=.020\end{array}$

Note. For continuous variables, means with standard deviations in parentheses and for categorical variables, percentages are presented. The group difference test for the former is a t-test while for the latter, it is a Chi-square test.

\section{Relations between Support for Reconciliation, Reconciliation Construals and Intergroup} Forgiveness

For Kurds (Table 4a), there was a significant relationship between support for reconciliation and intergroup forgiveness so that Kurds who were open to forgiveness, also supported reconciliation more. This relationship was stronger for those in Turkey. Different construals of reconciliation were not significantly related to support for reconciliation. The correlation between forgiveness and reconciliation construals did not reach to statistical significance, either. However, when looking at the correlation between forgiveness and the themes separately (rather than the two latent construals), in Belgium Kurds who were more likely to forgive endorsed more the emotion and dialogue themes $(r=.35, r=.26$, respectively, both $p \mathrm{~s}<.05)$. 
Table 4a

Correlation of study variables among Kurds

\begin{tabular}{lccc}
\hline & $\begin{array}{l}\text { Support for } \\
\text { Reconciliation }\end{array}$ & $\begin{array}{l}\text { Reconciliation } \\
\text { Construals }\end{array}$ & Forgiveness \\
\hline $\begin{array}{l}\text { Support for reconciliation } \\
\text { Reconciliation Construals }\end{array}$ & - & -.14 & $.35^{* *}$ \\
(1: rights vs. 0: dialogue) & -.16 & - & -.11 \\
Forgiveness & $* .28$ & -.09 & - \\
\hline
\end{tabular}

Note. Above the diagonal shows the correlations for Kurds in Turkey, below the diagonal shows the correlations for Kurds in Belgium. $* p<.05, * * p<.01$.

For Turks (Table 4b), the relationship between support for reconciliation and intergroup forgiveness showed an expected trend, similar to that of Kurds, but did not quite reach to statistical significance. The marginal significance was due to small sample sizes, when merging Turkish groups in Turkey and Belgium, the relationship between forgiveness and support for reconciliation became significant, $r=.25, p=.019$. Different construals of reconciliation were not significantly related to support for reconciliation, except for the relationship between unity construal of reconciliation and support for reconciliation: Those who endorse a unity construal of reconciliation were more likely to support reconciliation. The positive relationship between forgiveness and unity-based construal of reconciliation did not reach to statistical significance due to small sample sizes: When merging Turkish groups in Turkey and Belgium, the relationship between forgiveness and unity-based construal of reconciliation became marginally significant, $r=.24, p=.064$. Finally, unity and disarming construals were negatively correlated both in Turkey and in Belgium so that those who endorse unity construal were less likely to endorse disarming construal, $r=-.32, p=.014$.

Table $4 \mathrm{~b}$

Correlation of study variables among Turks

\begin{tabular}{lcccc}
\hline & $\begin{array}{l}\text { Support for } \\
\text { Reconciliation }\end{array}$ & $\begin{array}{c}\text { Reconciliation } \\
\text { Construals - }\end{array}$ & $\begin{array}{c}\text { Reconciliation } \\
\text { Construals - 2 }\end{array}$ & Forgiveness \\
\hline $\begin{array}{l}\text { Support for reconciliation } \\
\text { Reconciliation Construals - }\end{array}$ & - & $.36 \dagger$ & -.29 & $.26^{\mathrm{a}}$ \\
$\begin{array}{l}\text { (1: unity vs. 0: disarming) } \\
\text { Reconciliation Construals - }\end{array}$ & $.37^{*}$ & - & $-.92^{* *}$ & .30 \\
(1: rejection vs. 0: disarming) & -.13 & $-.35^{*}$ & - & -.19 \\
Forgiveness & $.25^{\mathrm{a}}$ & .22 & .13 & - \\
\hline
\end{tabular}

Note. Above the diagonal shows the correlations for Turks in Turkey, below the diagonal shows the correlations for Turks in Belgium. ${ }^{\mathrm{a}} p=.10, \dagger p=.05,{ }^{*} p<.05,{ }^{* *} p<.01$. 


\section{Discussion}

Given the importance of reconciliation for stable and long-lasting peace, what constitutes reconciliation is an intriguing question to researchers and policy-makers alike. Looking at the Kurdish conflict at a time when the so-called "peace process" was going on, we examined how Kurdish and Turkish group members in Turkey and in diaspora construe reconciliation and how they approach reconciliation and intergroup forgiveness as distinct yet related aspects of the peace-building process.

First, we analyzed reconciliation construals of Kurdish and Turkish respondents separately in order to allow for different meanings to emerge, while striving to preserve similar themes. We found seven themes for Kurdish respondents classified under two reconciliation construals and eight themes for Turkish respondents classified under three reconciliation construals.

Kurdish respondents' reconciliation construals tapped into both psychological and structural aspects of reconciliation. The "Rights" theme consisted of issues such as Kurdish rights, demands of language, education, right to political autonomy and equality. The "Freedom" theme referred to issues of free choice (concerning the political system, the importance of cultural codes etc.) and freedom to Abdullah Öcalan. The "Confederation" theme covered issues about Kurdish independence, establishment of an autonomous region or a confederation. Another theme was about "Emotions", when respondents talked about empathy, genuineness, trust and happiness. Another theme was about "Dialogue" when respondents talked about intergroup communication, the importance of talking and understanding each other. The theme "Recognition" referred to giving and getting recognition and respect. The last theme was called "Peace" which referred to constructing peace and ending the war.

These seven themes were grouped into two latent groups: those endorsing a dialoguebased construal of reconciliation (dialogue, recognition, emotions and peace) vs. those endorsing a rights-based construal (identity rights, freedom and confederative rights). This distinction is similar to the one between socio-emotional and instrumental routes to reconciliation in social and political psychology literature: while the former refers to a psychological process of mutual acceptance, communication and trust, the latter refers to structural changes that should accompany $i^{43}$. However, our findings also resonate with research beyond the psychology literature. In terms of the conflict frames in the ongoing Kurdish conflict, a demand for minority rights is not only a reason for the conflict, but also an essential element of the reconciliation from the Kurdish minority perspective ${ }^{44}$. These 
minority rights refer to the Kurdish demands about both identity (or cultural) rights (such as language) and political rights (such as local autonomy) ${ }^{45}$. In terms of change theories, Celik and Blum differentiate between the change at the individual and collective level, which can be likened to the distinction between socio-emotional and instrumental route to reconciliation. Change at the individual level such as change in the individual attitudes, emotions and behaviors should be accompanied by change at the collective level, such as change in social and economic policies ${ }^{46}$. Put differently, for achieving long-lasting peaceful relations a sincere dialogue between the conflicting parties that appears to be a socio-emotional necessity at the individual level should go hand in hand with cultural and political rights that require a change at the collective level. This is different from a majoritarian conservative strategy which responds to rights demands by shifting the focus towards revitalizing of past common identities and values on the basis of a common religion. ${ }^{47}$

Turning to Turkish construals of reconciliation, there were eight themes: some of the themes were similar with nuances, and some were new. Turks' construals of "Rights" focused on cultural practices such as demands of language and education, rather than right to political autonomy or equality. Turks as the majority group not only separated cultural and political rights but also came to accept -at least relatively- Kurds' cultural claims while ignoring political claims. This is also in line with lay persons' conflict frames described by Ulug and Cohrs: they found that while both Turks and Kurds endorse the cultural rights frame to some extent, Turks did not endorse political rights ${ }^{48}$. There was no separation of cultural from political rights for Kurds: For them as a minority group who have been forced to assimilate, Kurdish identity and culture have become inherently political ${ }^{49}$. The themes "Dialogue", "Emotions", "Peace" and "Recognition" were similar in content to Kurdish construals, referring to mutual talking, empathy, peace, and respect, respectively. There were also three new themes. The "Unity" theme referred to common identity, humanity, brotherhood, and integration (e.g. "We are united under the same roof"), and in few cases, to assimilation (i.e., "their adoption of our values"). "Disarming PKK" as a theme was coded separately than "Peace" as the former unilaterally focused on PKK's laying down arms. Third, "Rejection" theme was about not wanting reconciliation or a skeptical concern about the reconciliation process, implying that it was an ill-intentioned bargain. Finally, the themes of Confederation and Freedom did not show up for Turkish respondents. It is not surprising that these themes only appeal to Kurdish respondents. ${ }^{50}$

These eight themes were grouped into three latent groups: those endorsing a unitybased construal of reconciliation (unity, rights, dialogue, recognition, and emotions), those 
endorsing a Disarming PKK-based construal of reconciliation (disarming PKK and peace) and those rejecting reconciliation (Rejection of reconciliation). These construals were different from those endorsed by Kurds. First, the psychological and structural elements of reconciliation were not separate from the Turkish perspective. Unity-based construal of reconciliation involved both the unity and the rights themes - the latter referring to the structural or instrumental component of reconciliation so long as the cultural rights are concerned. From the dominant group's peace frame, this is about "giving cultural rights to Kurds". ${ }^{51}$ Dialogue, recognition and emotions such as empathy-the psychological or socioemotional component of reconciliation - fell under the same construal as unity and rights. From the Turkish perspective, it seems that as long as there is an understanding of common identity (i.e., unity), one can talk about cultural rights, dialogue, recognition and empathy for Kurds. Common Identity Theory in psychology supports this reasoning: ${ }^{52}$ If groups perceive themselves as part of a common identity, this may facilitate positive attitudes toward other groups. ${ }^{53}$ However, this was only the case for Turkish understanding of reconciliation. Studying the ethos of conflict, Cohrs and his colleagues found out that threats to brotherhood and unity were among the frequent conflict representations among Turks. ${ }^{54}$ Moreover, the emphasis on unity can also be seen deriving from a "fear of being divided" among Turks during the so-called peace process ${ }^{55}$. Both our finding and previous findings from Cohrs and colleagues are also in line with a unity understanding that carries an assimilative and exclusionary representation of Turkish identity deeply rooted in Turkish nationalism, a mainstream discourse in Turkey since the foundation of the Turkish Republic. ${ }^{56}$ Hence, from a Turkish perspective, unity appears to be a precondition for granting cultural rights, feeling empathy and giving recognition.

Secondly, among Turks, disarming PKK construal covered themes of both peace and disarming PKK, while the peace theme went together with themes such as dialogue, recognition and emotions - the psychological component of reconciliation-among Kurds. A possible interpretation would be that, for Turks, the peace process cannot be thought without unconditional disarming of PKK, a frame which already existed in the main discourse of the Turkish state during the "Compensation Law" period. ${ }^{57}$ In terms of conflict frames, disarming PKK goes together with the terrorism conflict frame for Turks, seeing the conflict between the Turkish state and PKK as the two relevant parties. ${ }^{58}$ Third, a cynical discourse appeared from Turks' reconciliation meanings: Some of the Turkish respondents did not believe in reconciliation or raised a skeptical concern about the intentions behind the reconciliation process. 
Let's turn to the relationships between perceptions of different facets of the peacebuilding process.

Reconciliation construals were not related to support for reconciliation for Kurdish respondents: Those having a dialogue or rights-based understanding of reconciliation were equally likely (or unlikely) to support reconciliation. The level of support for reconciliation was around the midpoint of the scale, thus not very high, and it was even lower among Kurds in Turkey than those in Belgium. On the other hand, for Turkish respondents, the unity construal was related to support for reconciliation: Turkish respondents with a claimed willingness to recognize Kurdish ethnic identity and cultural rights, with a longing for dialogue and positive emotions, along with an emphasis on unity and fraternity were also more willing to support reconciliation. This is in line with one of the main political discourses during the reconciliation process that underlined the theme of "peace and fraternity".59 Moreover and similar to Kurds, the level of support for reconciliation was around the midpoint of the scale, and it was lower among Turks in Turkey than those in Belgium.

Both Turks and Kurds in Turkey supported reconciliation less, and this is alarming in terms of constructing possible routes for peace-building in the proximal conflict context. Minorities in Europe could be more acculturated to non-conflicting multicultural codes of living and therefore more supportive of reconciliation. Belgium is a multicultural country composed of French, Flemish and German communities. ${ }^{60}$ From a social and political psychology perspective, the difference the national context creates could also be due to lower salience of the intergroup conflict (e.g., lack of an armed conflict) and lower salience of the physical and psychological intergroup boundaries between Kurds and Turks in Belgium. For instance, in Belgium both Turks and Kurds are a minority group and they stay in their segregated communities and politically organize around their ethnic allegiances. ${ }^{61}$ The relatively-lower Kurdish identification of Kurds in Belgium compared to those in Turkey in our study supports this latter reasoning about the salience of active (hot) intergroup conflict. However, the same may not apply symmetrically to Turkish groups: Levels of Turkish identification were equally high in Belgium and Turkey.

These findings should also be situated within the peace process during which this research was conducted. According to Çelik, the peace process turned out to be uncertain and vague and thus was not free from existential fears and anxieties of Turks as well as Kurds, what she calls 'ontological insecurity'. For instance, the reforms during the process did not secure cultural and political demands of the Kurds, such as language rights and local autonomy. This was accompanied by 'physical insecurity' felt at times due to physical attacks 
on both sides ${ }^{62}$. These insecurities might explain the relatively lower levels of support for reconciliation. Further reasons of the difference of reconciliation support between Belgium and Turkey might be derived from the insufficiency of Track II interventions which involve informal processes by engaging citizens in the peace process on a societal level during the formal conflict resolution negotiations. ${ }^{63}$ Indeed a recent research by Uluğ and Cohrs ${ }^{64}$ highlights that while the discourses endorsed by Track I actors (such as politicians) involve a terror perspective, discourses by Track II actors (such as experts from academia, NGOs, and media settings) is much more focused on democracy, rights and economy. Finally, it is crucial to remember the general fluctuations in public support depending on the government's political and election agenda. For instance, one of the public polls in 2013 (before our data collection) shows slow but steady increase in support for reconciliation, while a public poll from 2011 (during our data collection) showed resistance of Turks in Turkey in supporting concrete steps of reconciliation towards recognition of political and cultural rights of Kurds in Turkey (for example, recognition of Kurdish identity was slightly disagreed by Turks) with $29 \%$ of the sample stating democratic resolution and $32 \%$ stating oppressive and violent resolution for solving the "Kurdish problem". 65

Intergroup forgiveness was related to support for reconciliation for both Kurds and Turks: Those who support reconciliation are more likely to forgive. From a social and political psychology perspective, if both reconciliation and intergroup forgiveness can be considered as changes of motivations about the conflict as well as about the other group, it is not surprising that these are related constructs. ${ }^{66}$ The size of the correlation among Kurds is moderate and slightly higher in Turkey (versus in Belgium) suggesting that for Kurds in Turkey these two aspects of peace-building are more strongly related probably because of the contextual salience of the intergroup conflict and sharper boundaries between Kurds and Turks in Turkey, as mentioned above. The size of the correlation among Turks, however, is small-to-moderate and similar in both Turkey and Belgium.

Finally, we look at the relationship between forgiveness and reconciliation construals. For Kurdish respondents, forgiveness was not related to either construals of reconciliation. When looking at the relationship between forgiveness and the themes separately (rather than the two latent construals), Kurds endorsing the emotion and dialogue themes were more likely to forgive. For Turks, there was a positive relationship between forgiveness and unity-based construal of reconciliation so that those endorsing a unity-based construal of reconciliation were more likely to forgive. In the literature about forgiveness, emotions such as empathy and trust are considered facilitators of forgiveness. Similarly, Shnabel and colleagues have found 
that restoring damaged identities of both sides of the conflict via dialogue increases the readiness to reconciliation. ${ }^{67}$ Therefore it is not surprising that forgiveness, emotion and dialogue themes were positively related among Kurds; thereby suggesting a psychological need for open dialogue and positive emotions for initiating intergroup forgiveness. For Turks, it seems that forgiveness requires change of identities towards a common identity, along with emotions such as empathy and mutual dialogue. Both Yeğen and Ünlü draw attention to the changing dynamics of the acceptance of Kurds' existence in Turkey in a way that given their rejection of assimilation and quest for political autonomy, they are degraded from being 'prospective Turks' to 'pseudo-citizens' and they are seen as the deal-breakers of the 'Turkishness contract'. ${ }^{68}$ Therefore, any Turkish frame of reconciliation and forgiveness recently falls within a nationalistic nostalgia, an assimilative "last call" to Kurds, setting a precondition for reconciliation and forgiveness. From this line of reasoning it is also not a surprise to see that Turks' forgiveness go hand in hand with an assimilative unity construal of reconciliation. Finally, the level of intergroup forgiveness was above the midpoint of the scale for both Kurds and Turks, thus people believed that forgiveness was necessary to move forward. However, given that the cease fire and peace talks have been interrupted, support for forgiveness could be expected to be lower if measured today.

Although there were slight differences, construals of reconciliation and its relations to forgiveness and support for reconciliation seemed overall similar across Turkey and Belgium. This could be because immigrants from Turkey in Europe and in Belgium are strongly attached to their ethnic origin; they stay in closed communities, have strong ties with and follow news and politics from Turkey. ${ }^{69}$ When there were differences (as in the levels of support for reconciliation), they were due to the heightened salience of the conflict in Turkey. Our study contributes to the understanding of the understudied intergroup conflict between diaspora Turks and Kurds in Belgium. ${ }^{70}$ Future studies should look into the reasons for the difference in support for reconciliation, such as the salience of intergroup boundaries and endorsing multiculturalism. For instance, despite an increased expression of conflict between the younger generation of Kurds and Turks (such as in Sweden), there is also a growing discourse in diaspora as possible actors of peacebuilding which may explain increased support for reconciliation in Kurds in Belgium. ${ }^{71}$

One note of caution is that in this study respondents in both countries were highlyeducated, and they are not representative of the respective populations. Education level predicts political mobilization. For Kurds as a minority group, higher education may increase political mobilization for in-group rights, and for Turks, it may lead to higher support for 
minority rights. ${ }^{72}$ Although the findings of this research among educated young people is still important for the resolution of the intergroup conflict in Turkey, future studies should include both educated and uneducated segments of society. Another issue which might have affected the results is the disproportionate representation of male respondents which may be due to the interviewer's gender. Reflecting on the role of women in peacebuilding, specifically the unique discourse and efforts toward establishing the de-escalation of the conflict and starting the reconciliation in civil society, it is worth noting that the reconciliation themes that appeared in our research may still fall under the dominant male discourse in both Kurds and Turks but especially so in Turks in Turkey, which may explain the emphasis on "disarming PKK". ${ }^{73}$ Finally, since the reconciliation requires a change of perspectives of both parties in the conflict, this study included the Turkish perspective as well. However, the Turkish sample was small and only two-thirds responded for the meanings of reconciliation, which affected the strength of the correlations. This may tell us something about the (lack of) motivation of Turkish respondents to elaborate their answers (and possibly thoughts) about what reconciliation means. Despite small sample sizes, the fact that the results are consistent with the literature strengthens our conclusions.

Overall, this research sheds light on the questions what reconciliation means from the perspective of both minority and majority groups, how these meanings are related to intergroup forgiveness, and how these processes play out in Turkey and in diaspora. Beyond its theoretical contributions, it highlights potential pathways to reconciliation for an ongoing conflict. 
Notes

${ }^{1}$ Neuberg, et al., Religion and intergroup conflict, 198-206.
2 Spini, Elcheroth, and Fasel, The aftermath of war in the Former Yugoslavia, 3-23.
${ }^{3}$ Azcárate, Psychosocial dynamics of the armed conflict in Colombia.
${ }^{4}$ Bar-Tal and Bennink, "The nature of reconciliation", 11-38.
Kelman, "Reconciliation as identity change", 111-124.
Kelman, "Reconciliation from a social-psychological perspective", 15-32.
${ }^{5}$ Bar-Tal and Bennink, "The nature of reconciliation", 11-38.
${ }^{6}$ Shnabel and Nadler, A needs-based model of reconciliation, 116-132.
7 see for example, McLernon, Cairns, and Hewstone, Views on Forgiveness in Northern Ireland, 285-290;
Van Tongeren, Burnette, O’Boyle, Worthington, and Forsyth, A meta-analysis of intergroup forgiveness, 81-95.
${ }^{8}$ KONDA, "Biz Kimiz? Toplumsal Yapı Araştırması", 21-24;

Sirkeci, Kurdish Population in the Turkish Context, 149-175.

${ }^{9}$ Yeğen, Turkish nationalism and the Kurdish question, 119-151.

${ }^{10}$ Yıldız, "Turkey's Kurdish Conflict", 151-174.

${ }^{11}$ Mandıracı, "Turkey's PKK Conflict".

12 ICG, "Turkey and the PKK", 5-9;

Yeğen, Kurdish peace process in Turkey, 119-151.

${ }^{13}$ Yeğen, Kurdish peace process in Turkey, 119-151.

${ }^{14}$ Başer, "Kurdish Diaspora in Europe", 9-15, 30;

$\varnothing$ stergaard-Nielsen, Turks and Kurds in Germany and the Netherlands, 261-281.

${ }^{15}$ Alinia and Eliassi , Identity, Home(Land), and Politics of Belonging Among the Kurdish Diaspora, 73-81,

${ }^{16}$ But see Casier, Gatekeepers in homeland politics, 501-521.

17 JimmisVideos, "Muslims Riot in Belgium";

Koutroubas, Vloeberghs, and Yanasmayan, "Political, Religious and Ethnic Radicalisation", 51-80;

RésistanceS, "Les loups gris responsables d'actions terroristes à Bruxelles"..

${ }^{18}$ But see Casier, Gatekeepers in homeland politics, 501-521.

${ }^{19}$ Rigoni, Les mobilisations des Kurdes en Europe, 203-223.

${ }^{20}$ Bar-Tal and Bennink, "The nature of reconciliation", 11-38

Kelman, "Reconciliation from a social-psychological perspective", 15-32.

${ }^{21}$ Bar-Tal and Bennink, "The nature of reconciliation", 11-38

22 Nadler, Intergroup Reconciliation, 294.

23 Jeannotte, Promoting social integration, 1-15;

Bar-Tal \& Bennink, The nature of reconciliation, 11-38.

${ }^{24}$ Bar-Tal and Bennink, "The nature of reconciliation", 11-38;

Nadler, Intergroup Reconciliation, 294.

${ }^{25}$ But see for example Shnabel and Nadler, A needs-based model of reconciliation, 116-132

${ }^{26}$ Licata et al., Perceived outgroup (dis)continuity, 179-192;

Noor, Brown, and Prentice, Intergroup reconciliation in Northern Ireland, 481-495;

Čehajić et al., Forgive and forget, 351-368.

${ }^{27}$ For reconciliation as trust and collaboration see Kanazayire, Licata, Mélotte, Dusingizemungu, and Azzi, Reconciliation sentiments, 489-504;

Mukashema and Mullet, Reconciliation sentiment in Rwanda, 25-39;

for reconciliation as the need to talk to and interact see Noor, Brown, Gonzalez, Manzi, and Lewis, Intergroup reconciliation in Northern Ireland, 481-495.

${ }^{28}$ Bar-Tal, Socio-psychological foundations of intractable conflicts, 1430-1453.

${ }^{29}$ For outgroup (dis)trust see Çelebi, Verkuyten, Köse, and Maliepaard, Out-group trust and conflict understandings, 64-75;

for attitudes towards reconciliation see Bar-Tal, "Intractable conflicts", 24.

${ }^{30}$ Çelik and Blum, "Reconciliation in the Kurdish issue", 131-152;

See also Bilali, Downsides of a shared national identification, 21-38;

and Çelebi et al., Out-group trust and conflict understandings, 64-75.

${ }^{31}$ Uluğ and Cohrs, Kurdish conflict frames in Turkey, 109-119;

Uluğ and Cohrs, Ethos of conflict, 1-22.

${ }^{32}$ Van Dijk, "Discourse, power and access", $90-92$. 
${ }^{33}$ Enright, Freedman, and Rique, Interpersonal Forgiveness, 46-47.

${ }^{34}$ van Tongeren et al., Meta-analysis of intergroup forgiveness, 81-95.

${ }^{35}$ Nadler and Shnabel. Intergroup reconciliation, 93-125.

${ }^{36}$ See for example Baysu and Duman, Why does identity matter?, 43-51;

McLernon et al., Views on Forgiveness, 285-290;

And for a review van Tongeren et al., Meta-analysis of intergroup forgiveness, 81-95.

${ }^{37}$ KONDA, "Biz Kimiz? Toplumsal Yapı Araştırması", 21-24;

Sirkeci, Kurdish Population in the Turkish Context, 149-175

${ }^{38} \mathrm{Hjort}$ and Frisen, Ethnic identity and reconciliation, 141-163.

${ }^{39}$ Moeschberger, Dixon, Niens and Cairns, Forgiveness in Northern Ireland, 115-121.

${ }^{40}$ Postmes, Haslam, and Jans, Single-item measure of social identification, 597-617.

${ }^{41}$ Hallgren, Inter-rater reliability for observational data, 23-24.

${ }^{42}$ McCutcheon, "Latent class analysis".

${ }^{43}$ Theoretically this distinction is in line with the view of reconciliation in the papers by Nadler and Shnabel (Intergroup reconciliation, 93-125) and Bar-Tal and Bennink ("The nature of reconciliation", 11-38). Empirically though the following research measures reconciliation only as a psychological change: Kanazayire et al., Identification with Rwanda, 489-504; Noor, Brown, and Prentice, Precursors and mediators of intergroup reconciliation, 481-495; Staub, Reconciliation after genocide, 867-894.

${ }^{44}$ For conflict frames see Bilali, "Downsides of a shared national identification", 21-38;

Çelik and Blum, "Reconciliation in the Kurdish issue", 131-152;

and Uluğ and Cohrs, Kurdish conflict frames in Turkey, 109-119.

${ }^{45}$ While we speak of language rights as cultural or identity rights as separate from political claims such as political autonomy or federation, we do not deny that identity can also be perceived as a political position. This would be in line with our Kurdish respondents' position for whom cultural and political goes hand in hand.

${ }^{46}$ for a more detailed information on the theories of change in conflict resolution, see Çelik and Blum,

"Reconciliation in the Kurdish issue", 131-152

${ }^{47}$ Bakıner, "Politics of memory and majoritarian conservatism", 691-708;

Çelik and Blum, "Reconciliation in the Kurdish issue", 131-152;

see also note Nadler and Shnabel. "Intergroup reconciliation", 93-125.

48 Uluğ and Cohrs, Kurdish conflict frames in Turkey, 109-119

${ }^{49}$ Schäfers ("Being sick of politics") discusses how the Kurdish female singers strategically distinguish the cultural domain from the political. The article also explains how and why Kurdish identity is a political existence ${ }^{50}$ Uluğ and Cohrs, Kurdish conflict frames in Turkey, 109-119;

Uluğ and Cohrs, Ethos of conflict, 1-22.

${ }^{51}$ Başer and Çelik ("Imagining peace in a conflict environment") focus on Kurdish youths' framing of the Kurdish issue as well as the dominant peace frame in Turkey

${ }^{52}$ Gaertner and Dovidio, "Reducing intergroup bias".

${ }^{53}$ Baysu and Duman, Why does identity matter?, 43-51.

${ }^{54}$ Cohrs, Uluğ, Stahel and Kışlığlu, "Ethos of Conflict", 33-45.

${ }^{55} \mathrm{~A}$ clear demonstration of this relationship can be seen in the words of a Turkish respondent in one of the workshops initiated by civil society organizations during the peace process "If I see that my Kurdish friends have an understanding of nationalism beyond asking for cultural rights, such as an ethnic nationalism, it is right to have a fear of being divided', cited in Çelik, "The Kurdish issue and levels of ontological security" p.57

56 Ünlü, "The Kurdish struggle and Turkishness Contract", 397-405;

Yeğen, "'" Prospective-Turks" or" Pseudo-Citizens:" Kurds in Turkey",597-615.

${ }^{57}$ According to Biner, "The right to compensation and the right to justice in Turkey", p.73 "The law was designed to compensate citizens who had incurred material damages as a result of the military conflict between PKK and Turkish armed forces"

${ }^{58}$ For conflict frames see Bilali, "Downsides of a shared national identification", 21-38;

Çelik and Blum, "Reconciliation in the Kurdish issue", 131-152;

and Uluğ and Cohrs, "Kurdish conflict frames in Turkey", 109-119.

${ }^{59}$ Ensaroğlu, "Turkey's Kurdish Question and the Peace Process" .

${ }^{60}$ Bousetta and Swyngedouw, La citoyenneté de l'Union Européenne, 1636-1999.

${ }^{61}$ for Germany and the Netherlands see $\varnothing$ stergaard-Nielsen, Turks and Kurds in Germany and the Netherlands, 261-281.

${ }^{62}$ This is not to say that the insecurities felt by both groups are symmetric, lease see Çelik, "The Kurdish issue and levels of ontological security." 
${ }^{63}$ Çelik and Blum, "Track II interventions and the Kurdish question in Turkey, 51-81; Çelik, "The Kurdish issue and levels of ontological security" ,52-70.

${ }^{64}$ Uluğ and Cohrs, " A Comparison of Track I and Track II Actors", 147-172.

${ }^{65}$ KONDA, "Konda Barometresi: Temalar, Sorun Çözme;

KONDA, "Kürt meselesinde algı ve beklentiler.

${ }^{66}$ Bar-Tal and Bennink, "The nature of reconciliation", 11-38.

Nadler and Shnabel. Intergroup reconciliation, 93-125.

van Tongeren et al., Meta-analysis of intergroup forgiveness, 81-95.

${ }^{67}$ Shnabel, Nadler, Ullrich, Dovidio, and Carmi, Promoting reconciliation, 1021-1030

68 Ünlü, "The Kurdish struggle and Turkishness Contract", 397-405;

Yeğen, "Turkish nationalism and the Kurdish question", 119-151;

Yeğen, "' Prospective-Turks" or" Pseudo-Citizens:" Kurds in Turkey", 597-615.

${ }^{69}$ Baser The Kurdish Diaspora in Europe;

Phalet, Baysu, and van Acker, "Ethnicity and migration in Europe", 142-147.

${ }^{70}$ Baysu and Duman, Why does identity matter?, 43-51.

Van Bruinessen, Shifting national and ethnic identities, 39-52.

${ }^{71}$ Alinia and Eliassi, "Identity, home (land) and politics of belonging among the Kurdish diaspora", 73-81;

Başer, " Kurdish Diaspora and the Peace Process in Turkey", 1-25.

72 For Turkish immigrants in Europe see for example Fleischmann, Phalet, and Klein, Religious identification and politicization, 628-648.

${ }^{73}$ Al-Ali and Taş, "Kurdish and Turkish Women's Rights Activism for Peace", 54-375. 


\section{Bibliography}

Al-Ali, N., and Taş, L.. "“War Is like a Blanket" Feminist Convergences in Kurdish and Turkish Women's Rights Activism for Peace." Journal of Middle East Women's Studies, 13 (3), (2017): 354-375.

Alinia, M., and Eliassi, B. "Temporal and generational impact on identity, home (land) and politics of belonging among the Kurdish diaspora." Nordic Journal of Migration Research, 4 (2), (2014): 73-81.

Azcárate, Camilo. "Psychosocial dynamics of the armed conflict in Colombia." Online Journal of Peace and Conflict Resolution 2, no. 1 (1999).

Bakiner, Onur. "Is Turkey coming to terms with its past? Politics of memory and majoritarian conservatism." Nationalities Papers 41 (5), (2013): 691-708.

Baysu, G., and DumanY.. "Why does identity matter? A Two-Path Model to Intergroup Forgiveness via In-group Bias and Outgroup Blame”. Psychological Research, 19(1), (2016): $43-51$.

Başer, B. The Kurdish Diaspora in Europe: Identity formation and political activism. Boğaziçi University-TÜSİAD Foreign Policy Forum Research Report, 2013. http://dispolitikaforumu.com/wp-content/uploads/2013/10/Bahar_Baser_RR_01_2013.pdf

Başer, B. "Intricacies of Engaging Diasporas in Conflict Resolution and Transitional Justice: The Kurdish Diaspora and the Peace Process in Turkey." Civil Wars (2017): 1-25. Başer, Zeynep and Çelik, Ayşe Betül, (2014) "Imagining peace in a conflict environment: Kurdish youths' framing of the Kurdish issue in Turkey”, Patterns of Prejudice, Vol.48, No.3, 265-285

Bar-Tal, D. "Socio-psychological foundations of intractable conflicts". American Behavioral Scientist, 50, (2007): 1430-1453. doi:10.1177/0002764207302462.

Bar-Tal, D.. Intractable conflicts: Socio-psychological foundations and dynamics. New York, NY: Cambridge University Press, 2013.

Bar-Tal, D., and G. H. Bennink."The nature of reconciliation as an outcome and as a process". In From conflict resolution to reconciliation, edited by Y. Bar-Siman-Tov, 11-38. Oxford: Oxford University Press, 2004.

Bilali, R.. "The downsides of a shared national identification for minority group outcomes in intergroup conflicts in assimilationist societies”. British Journal of Social Psychology, 53, (2014): 21-38. doi:10.1111/bjso.12012. 
Biner, Zerrin Özlem. "The logic of reconciliation: between the right to compensation and the right to justice in Turkey." Humanity: An International Journal of Human Rights, Humanitarianism, and Development 4, 1 (2013): 73-91.

Bousetta, H. and M. Swyngedouw. La citoyenneté de l'Union Européenne et l'enjeu de Bruxelles. Brussels: Courier Hebdomadaire de CRISP, 1636, 1999. doi:10.3917/cris. 1636.0001 .

Casier, M. "Neglected middle men? Gatekeepers in homeland politics. Case: Flemish nationalists' receptivity to the plight of Turkey's Kurds”. Social Identities 17, no: 4 (2011): 501-521. doi:10.1080/13504630.2011.587305.

Cohrs, J. C., Ö. M. Uluğ, L. Stahel, and R. Kışlıoşlu . "Ethos of conflict and beyond: Differentiating social representations of conflict". In The social psychology of intractable conflicts: Celebrating the legacy of Daniel Bar-Tal, edited by E. Halperin and K. Sharvit, Vol. 1, 33-45. New York, NY: Springer, 2015. http://dx.doi.org/10.1007/978-3-319-17861-5_3

Čehajić, S., R. Brown, and E. Castano. "Forgive and forget? Antecedents and consequences of intergroup forgiveness in Bosnia and Hercegovina". Political Psychology 29, (2008): 351-368. doi:10.1111/j.1467-9221.2008.00634.x.

Çelebi, E., M. Verkuyten, T. Köse, and M. Maliepaard. "Out-group trust and conflict understandings: the perspective of Turks and Kurds in Turkey”. International Journal of Intercultural Relations 40, (2014): 64-75. doi:10.1016/j.ijintrel.2014.02.002.

Çelik, Ayşe Betül. "The Kurdish issue and levels of ontological security." The Kurdish issue and levels of ontological security. Abingdon, Oxon; New York: Routledge (2015): 5270.

Çelik, A. "The need for Reconciliation in the Kurdish issue: Why, how and with whom? [Kürt meselesi'ni dönüştürmede toplumsal mutabakat ihtiyacı: Neden, nasıl, kimle?]”. In Conflict Resolution and Peace [Çatışma Çözümleri ve Barış], edited by M. Aktaş, 131-152. İstanbul: İletişim, 2014.

Çelik, A. B., and A. Blum. "Track II interventions and the Kurdish question in Turkey: An analysis using theories of change approach". International Journal of Peace Studies 12, no: 2 (2007): 51 - 81. http://www.jstor.org/stable/41852962.

Enright, R. D., S. Freedman, and J. Rique. "The psychology of interpersonal forgiveness". In Exploring forgiveness, edited by R. D. Enrigh and J. North, 46-62. Madison, WI: University of Wisconsin Press, 1998. 
Ensaroğlu, Y. “Turkey’s Kurdish Question and the Peace Process”. Insight Turkey 15, no: 2 (2013): 12-13.

http://www. insightturkey.com/turkeys-kurdish-question-and-thepeaceprocess/articles/314.

Fleischmann, F., K. Phalet, and O. Klein.. "Religious identification and politicization in the face of discrimination. Support for political Islam and political action among the Turkish and Moroccan Second Generation in Europe”. British Journal of Social Psychology 50, no: 4 (2011): 628-648. doi:10.1111/j.2044-8309.2011.02072.x.

Gaertner, S. L., and J. F. Dovidio. Reducing intergroup bias: The common in-group identity model. Philadelphia: Psychology Press, 2000.

Hallgren, K. A. “Computing inter-rater reliability for observational data: an overview and tutorial". Tutorials in quantitative methods for psychology, 8(1), (2012): 23-24.

Hjort, H. and A. Frisen. "Ethnic identity and reconciliation: Two main tasks for the young in Bosnia-Herzegovina”. Adolescence 41, no: 161 (2006):141-163.

ICG (International Crisis Group). Turkey and the PKK: Saving the Peace Process, 2014. https://d2071andvip0wj.cloudfront.net/turkey-and-the-pkk-saving-the-peaceprocess.pdf.

Jeannotte, S. M. "Promoting social integration - A brief examination of concepts and issues". Report for the Experts Group Meeting of U.N. Department of Economic and Social Affairs (2008).

http://www.un.org/esa/socdev/social/meetings/egm6_social_integration/documents/Jea nnotte_Concepts.pdf

JimmisVideos. "Muslims Riot in Belgium 06/11/2011 -- Turks and Kurds in Savage Street War in Antwerp" [Video file]. (2011, November 6). Retrieved from https://www.youtube.com/watch?v=2iaYblvFvV0

Kanazayire, C., L. Licata, P. Mélotte, J. P. Dusingizemungu, and A. E. Azzi. "Does identification with Rwanda increase reconciliation sentiments between genocide survivors and non-victims? The mediating roles of perceived intergroup similarity and self-esteem during commemorations". Journal of Social and Political Psychology 2, no: 1 (2014): 489-504. doi:10.5964/jspp.v2i1.319.

Kelman, Herbert C. "Reconciliation as identity change: A social psychological perspective".In From conflict resolution to reconciliation, edited by Yaacov BarSiman-Tov, (2004): 111-124. Oxford: Oxford University Press. 
Kelman, Herbert C. . "Reconciliation from a social-psychological perspective." In Social Psychology of Intergroup Reconciliation, edited by A. Nadler, T. Malloy and J.D. Fisher, 15-32. Oxford and New York: Oxford University Press, 2008.

KONDA. Biz Kimiz? Toplumsal Yapı Araştırması [Who are we? Research on social structures]. Istanbul, Turkey: Konda Araştırma ve Danışmanlık, 2006. http://konda.com.tr/wpcontent/uploads/2017/02/2006_09_KONDA_Toplumsal_Yapi.pdf

KONDA. Kürt meselesinde algl ve beklentiler [Perception and epectations in Kurdish Issue]. Konda Barometer: Themes, Problem Solving]. Istanbul, Turkey: Konda Araştırma ve Danışmanlık, 2011.

KONDA. Konda Barometresi: Temalar, Sorun Çözme [Konda Barometer: Themes, Problem Solving]. Istanbul, Turkey: Konda Araştırma ve Danışmanlık, 2013. http://konda.com.tr/wpcontent/uploads/2017/03/KONDA_1311_SORUN_\%C3\%87\%C3\%96ZME.pdf

Koutroubas, T., W. Vloeberghs, and Yanasmayan, Z. "Political, Religious and Ethnic Radicalisation among Muslims in Belgium”. In Ethno-Religious Conflict in Europe: Typologies of Radicalisation in Europe's Muslim Communities, edited by M. Emerson 51-80. Brussels: Centre European Policy Studies, 2009.

Licata, L., O. Klein, W. Saade, A. E. Azzi, and N. R. Branscombe. "Perceived outgroup (dis)continuity and attribution of responsibility for the Lebanese civil war mediate effects of national and religious subgroup identification on intergroup attitudes". Group Processes and Intergroup Relations 15, no: 2 (2012): 179-192. doi:10.1177/1368430211414445.

Mandırac1, B. Turkey's PKK Conflict: The Death Toll [International Crisis Group Report]. (2016, July 20). Retrieved from http://blog.crisisgroup.org/europe-centralasia/2016/07/20/turkey-s-pkk-conflict-the-rising-toll/

McCutcheon, A. C. Latent class analysis. Beverly Hills: Sage Publications, 1987.

McLernon, F., E. Cairns and M. Hewstone Views on Forgiveness in Northern Ireland, Peace Review: A Journal of Social Justice, 14, no: 3 (2002): 285-290.

Moeschberger, S.L., D. N. Dixon, U. Niens, and E. Cairns. "Forgiveness in Northern Ireland: An empirical model for peace in the midst of the "troubles". Peace and Conflict Journal: Journal of Peace Psychology 41, (2005): 115-121. doi:10.1207/s15327949pac1102_5. 
Mukashema, I., and E. Mullet. "Reconciliation sentiment among victims of genocide in Rwanda: Conceptualizations, and relationships with mental health". Social Indicators Research 99, (2010): 25-39

Nadler, A. "Intergroup reconciliation: Definitions, processes and future directions". In The Oxford handbook of intergroup conflict, edited by L. Tropp, 291-309. New York, NY: Oxford University Press, 2012.

Nadler, A., and N. Shnabel. "Intergroup reconciliation: Instrumental and socio-emotional processes and the needs-based model". European Review of Social Psychology, 26, no: 1 (2015): 93-125. doi: 10.1080/10463283.2015.1106712

Neuberg, S. L., C. M. Warner, S. A. Mistler, A. Berlin, E. D. Hill, J. D. Johnson, G. FilipCrawford et al. "Religion and intergroup conflict: Findings from the Global Group Relations Project”. Psychological Science 25, no: 1 (2014):198-206. doi: $10.1177 / 0956797613504303$

Noor, M., R. Brown, and G. Prentice. "Precursors and mediators of intergroup reconciliation in Northern Ireland: A new model”. British Journal of Social Psychology 47, (2008): 481-495. doi: 10.1348/014466607X238751

Noor, M., R. Brown, R. Gonzalez, J. Manzi, and C. A. Lewis. “On positive psychological outcomes: What helps groups with a history of conflict to forgive and reconcile with each other?” Personality and Social Psychology Bulletin 34, (2008):819-832. doi:10.1177/0146167208315555.

Østergaard-Nielsen, E. K. "Transnational political practices and the receiving state: Turks and Kurds in Germany and the Netherlands". Global Networks 1, no: 3 (2001): 261-281. doi:10.1111/1471-0374.00016.

Postmes, T., S. A. Haslam, and L. Jans. "A single-item measure of social identification: Reliability, validity, and utility”. British Journal of Social Psychology, 52, no: 4 (2013): 597-617. doi:10.1111/bjso.12006.

Phalet, K., G. Baysu, and K. van Acker. Ethnicity and migration in Europe. In International Encyclopedia of the Social and Behavioral Sciences, edited by J. Wright, and X. Chryssochoou, 2nd ed, 142-147, 2015. doi:10.1016/B978-0-08-097086-8.24040-3.

RésistanceS. "Les loups gris responsables d'actions terroristes à Bruxelles - 12/10/2007” [News coverage]. (2007, October 22). Retrieved from http://www.resistances.be/loupsgris03.html

Rigoni, I. "Les mobilisations des Kurdes en Europe”. Revue européenne des migrations internationales 14 (3), (1998): 203-223. 
Schäfers, M. "Being sick of politics: The production of dengbêjî as Kurdish cultural heritage in contemporary Turkey". European Journal of Turkish Studies [Online], 20, (2015), http://ejts.revues.org/5200

Shnabel, N., and A. Nadler. "A needs-based model of reconciliation: Satisfying the differential emotional needs of victim and perpetrator as a key to promoting reconciliation." Journal of Personality and Social Psychology, 94, (2008): 116-132. doi:10.1027/1864-9335/a000148

Shnabel, N., A. Nadler, J. Ullrich, J. F Dovidio, and D. Carmi. "Promoting reconciliation through the satisfaction of the emotional needs of victimized and perpetrating group members: The needs-based model of reconciliation." Personality and Social Psychology Bulletin, 35, (2009): 1021- 1030. doi:10.1177/0146167209336610

Sirkeci, I.. "Exploring the Kurdish Population in the Turkish Context". GENUS, International Journal of Demography 56, no: 1-2 (2005): 149-175.

\section{http://works.bepress.com/sirkeci/14/}

Spini, Dario, Guy Elcheroth, and Rachel Fasel. "Towards a community approach of the aftermath of war in the Former Yugoslavia: Collective experiences, social practices, and representations." In War, Community, and Social Change, pp. 3-23. Springer New York, 2014.

Staub, E. "Reconciliation after genocide, mass killing, or intractable conflict: Understanding the roots of violence, psychological recovery, and the steps toward a general theory." Political Psychology, 27, (2006): 867-894. doi:10.1111/j.1467-9221.2006.00541.x.

Uluğ, Ö. M., and J. C. Cohrs. “An exploration of lay people’s Kurdish conflict frames in Turkey." Peace and Conflict: Journal of Peace Psychology, 22, no: 2 (2016): 109-119. doi:10.1037/pac0000165.

Uluğ, Ö. M., and Cohrs, J. C. “Examining the ethos of conflict by exploring lay people's representations of the Kurdish conflict in Turkey." Conflict Management and Peace Science. (2017): 1-22. doi: 10.1177/0738894216674969

Uluğ, Özden Melis, and J. Christopher Cohrs. "How Do Experts Differ from Politicians in Understanding a Conflict? A Comparison of Track I and Track II Actors." Conflict Resolution Quarterly 35, no. 2 (2017): 147-172.

Ünlü, Barış. "The Kurdish struggle and the crisis of the Turkishness Contract." Philosophy \& Social Criticism 42, no. 4-5 (2016): 397-405. 
Van Bruinessen, M. "Shifting national and ethnic identities: The Kurds in Turkey and the European Diaspora." Journal of Muslim Minority Affairs 18, no: 1 (1998): 39-52. doi:10.1080/13602009808716392.

van Dijk, T.A. "Discourse, power and access". In Texts and Practices: Readings in Critical Discourse Analysis, edited by C.R. Caldas-Coulthard, and M. Coulthard, 84-104. Routledge, London, 1996.

Van Tongeren, D. R., J. L. Burnette, E. O’Boyle, E. L. Worthington and D. R. Forsyth. “A meta-analysis of intergroup forgiveness." The Journal of Positive Psychology: Dedicated to furthering research and promoting good practice, 9, no: 1 (2014): 81-95.

Yeğen, M. "Turkish nationalism and the Kurdish question." Ethnic and Racial Studies, 30, no: 1 (2007): 119-151.

Yeğen, Mesut. "" Prospective-Turks" or" Pseudo-Citizens:" Kurds in Turkey." The Middle East Journal 63, no. 4 (2009): 597-615.

Yeğen, M. "The Kurdish peace process in Turkey: Genesis, evolution and prospects." Global Turkey in Europe, 2015. http://www.iai.it/sites/default/files/gte_wp_11.pdf.

Y1ldı, K. “Turkey's Kurdish Conflict: Pathways to Progress”. Insight Turkey 14, no: 4 (2012):151-174.

http://file.insightturkey.com/Files/Pdf/20121030112907_insight_turkey_vol_14_no_4 2012 yildiz.pdf. 